\title{
MRI Imaging of Craniopharyngioma
}

\author{
Lokesh $\mathrm{R}^{1 *}$, Dinesh $\mathrm{S}^{1}$, Narvir $\mathrm{C}^{1}$, Pooja G ${ }^{2}$ and Manjuswamy $\mathrm{HR}^{2}$ \\ ${ }^{1}$ Department of Radio-diagnosis, Dr. Rajendra Prasad Government Medical College, \\ India \\ ${ }^{2}$ Department of Anaesthesia, Dr. Rajendra Prasad Government Medical College, India
}

\section{Case Report \\ Volume 3 Issue 1}

Received Date: December 12, 2018

Published Date: January 08, 2019

*Corresponding author: Lokesh Rana, Assistant Professor, Department of Radio-diagnosis, Dr. Rajendra Prasad Government Medical College, Kangra at Tanda, Himachal Pradesh, India, Tel: 9418059266; Email: poojalokesh2007@gmail.com

\section{Abstract}

It is a benign epithelial tumour arising from squamous cell rests in the sellar or suprasellar region arising from involuted Rathke-hypophyseal duct. We present two cases one 18 year old female another 12 year female with characteristic MR imaging features.

Keywords: Cystic; Supresellar

Abbreviation: MRI: Magnetic Resonance Imaging; FLAIR: Fluid-Attenuated Inversion Recovery; GRE: Gradient Recalled Echo.

\section{Case 1}

We present a case of 12 year female presenting with headache, vomiting and visual disturbances in the form of hemianopsia. MRI images [1-3] show a well-defined multiloculated multicystic supra-sellar mass with enhancement of solid component and wall on post gadolinium images (Figures $1(\mathrm{~A}-\mathrm{H})$ ).

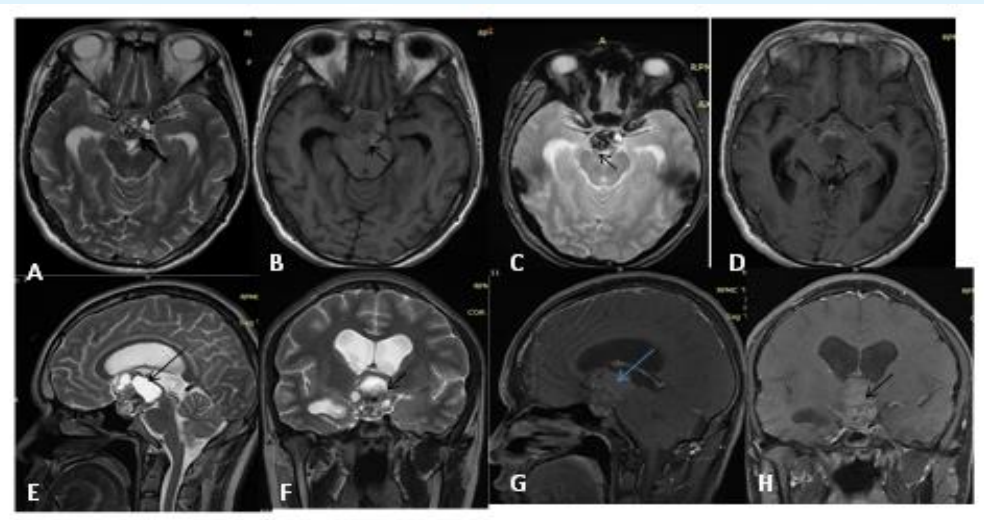

Figure 1(A-H): A 18 year old female presenting with headache and vomiting for 5 months MR images shows multiloculated solid cystic mass in suprasellar region which is obliterating the 3rd ventricle and causing lateral ventricle prominence as seen in axial T2W, T1W, GRE, POST CONTRAST (A-D): Saggital T2W, POST CONTRAST (E,G): Coronal T2W and POST CONTRAST (F,H): shown by arrow. Axial GRE Image clearly shows area of blooming. On postcontrast images it shows enhancement of the solid component. 


\section{Clinical Radiology \& Imaging Journal}

\section{Case 2}

The $2^{\text {nd }}$ case of 18 year female presenting with headache and vomiting MRI was [2,3] done which shows multiloculated solid cystic mass in suprasellar region which is obliterating the 3 rd ventricle and causing lateral ventricle prominence. On post-contrast images it shows enhancement of the solid component (Figures 2(A-I).

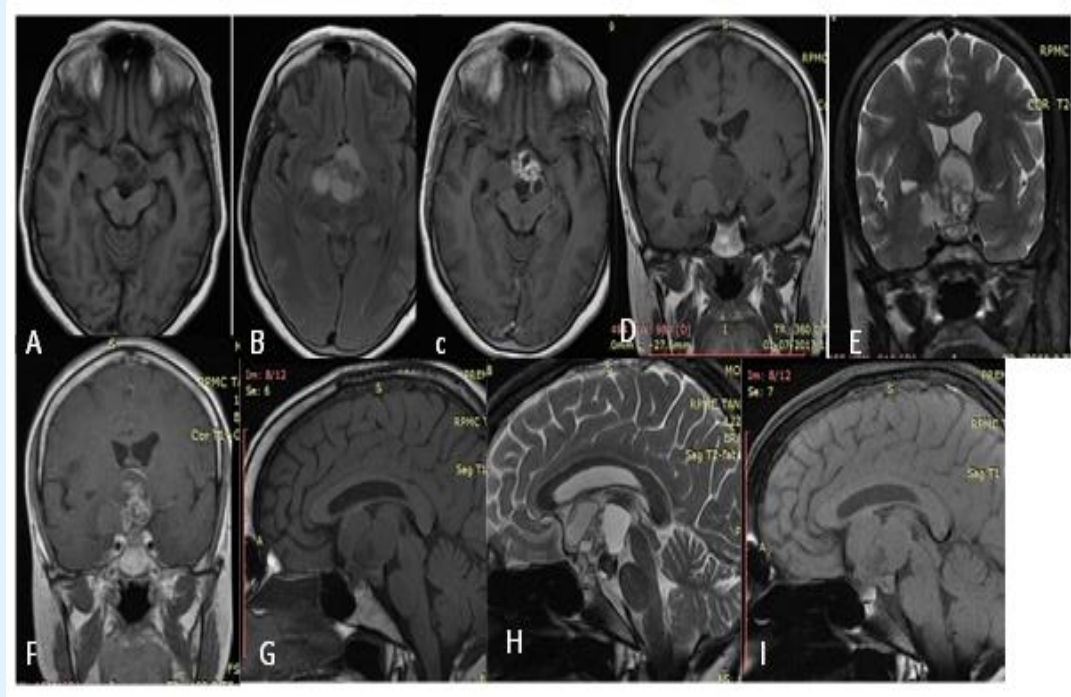

Figure 2(A-I): A 12 year Female child presenting with headache, vomiting and visual disturbances MRI images shows a well-defined multiloculated multisystem supra-sellar mass with enhancement of solid component and wall on post gadolinium images. The Axial T1W, FLAIR, POST CONTRAST (A-C): Coronal T1W, T2W and POST CONTRAST (D-F): Saggital T1W, T2W and POST CONTRAST (G-I): and wall on post gadolinium images.

\section{Discussion}

It is a benign epithelial tumour arising from squamous cell rests in the sellar or suprasellar region arising from involuted Rathke-hypophyseal duct [2,4].

\section{Clinical Presentation}

Peak age of presentation is 10-12 in case of adamantinomatous and $45-60$ in case of papillary tumours. Most common symptoms are headache, vomiting and visual (bitemporal hemianopsia) and symptoms due to hormonal deficiencies $[2,4,5]$.

\section{Key Imaging Diagnostic Clues}

a) Cystic suprasellar mass with enhancing solid component and calcification $[1,3,6,7]$.

\section{Differentials}

- Rathke cleft Cyst-no solid component, no calcification

- Macroadenoma-Intrasellar, no calcification

\section{- Teratoma-presence of fat $[1,6,7]$}

The T1 bright signal intensity of craniopharyngiomas could be secondary to high protein content, cholesterol, mild calcification or hemorrhage. Gradient images depict the calcification more clearly as it bloom. There is prevalence of T1 bright signal intensity and calcification on CT scans in the various types of craniopharyngiomas was similar to those reported in previous studies. Cystic change on T2 weighed images was a common finding in both adamantinomatous type and papillary type. In contrast to T1 bright signal intensity and calcification on CT scans, cystic change on T2 weighted images was not helpful for the differential diagnosis between two types.

\section{Conclusion}

It is a benign epithelial tumour arising from squamous cell rests in the suprasellar region arising from involuted Rathke-hypophyseal duct $[2,4,5]$. It has a characteristic MR imaging features i.e. suprasellar, cystic, solid 


\section{Clinical Radiology \& Imaging Journal}

component which distinguish from other masses in this region [5].

\section{References}

1. Lee $\mathrm{IH}$, Zan E, Bell WR, Burger PC, Sung H, et al. (2016) Craniopharyngiomas: radiological differentiation of two types. J Korean Neurosurg Soc 59(5): 466.

2. Bunin GR, Surawicz TS, Witman PA, Preston-Martin S, Davis F, et al. (1998) The descriptive epidemiology of craniopharyngioma. J Neurosurg 89(4): 547-551.

3. Eldevik OP, Blaivas M, Gabrielsen TO, Hald JK, Chandler WF (1996) Craniopharyngioma: radiologic and histologic findings and recurrence. Am J Neuroradiol 17(8): 1427-1439.
4. Crotty TB, Scheithauer BW, Young WF Jr, Davis DH, Shaw EG, et al. (1995) Papillary craniopharyngioma: a clinicopathological study of 48 cases. J Neurosurg 83(2): 206-214.

5. De Vile CJ, Grant DB, Kendall BE, Neville BG, Stanhope $\mathrm{R}$, et al. (1996) Management of childhood craniopharyngioma: can the morbidity of radical surgery be predicted?. J Neurosurg 85(1): 73-81.

6. Curran JG, O'Connor E (2005) Imaging of craniopharyngioma. Childs Nerv Syst 21(8-9): 635639.

7. Ahmadi J, Destian S, Apuzzo ML, Segall HD, Zee CS (1992) Cystic fluid in craniopharyngiomas: MR imaging and quantitative analysis. Radiology 182(3): 783-785. 